\title{
Life Satisfaction A Dual Role Woman
}

\author{
Ria $\operatorname{Yanah}^{\bowtie}$, Palupiningdyah \\ Departement of Management, Faculty of Economics, Universitas Negeri Semarang, Indonesia
}

\section{Article Information \\ Article History: \\ Received February 2020 \\ Approved March 2020 \\ Published September 2020}

Keywords:

Authentic Leadership,

Creativity, Organiza-

tional Citizenship Behavior,

Employee Performance.

\begin{abstract}
This study aims to Determine the effect of work family conflict and work engagement on life satisfaction through work life balance as a mediating variable of study in female nurses at RSI who are married. The type and design of research used in this study is quantitative research. Sampling in this study using proportional sampling sampling technique and Obtained sample size that must be used is 118 female nurses who are married, the analytical method used is the instrument test (validity and reliability), classic assumption test, and hypothesis testing with the application of SPSS 23. Data collection methods using interviews, questionnaires, and literature studies. The results of this study indicate that five hypotheses were accepted, and two hypotheses were rejected. So it can be seen that work family conflict has a negative and not significant effect on life satisfaction. Work engagement has a positive and significant effect on life satisfaction. Work family conflict has a negative and significant effect on work life balance. Work engagement has a positive and significant effect on work life balance. Whereas the work life balance is only Able to mediate the relationship between work engagement and life satisfaction. Suggestions for future research are to develop other variables that can mediate the relationship of work family conflict in the life satisfaction of female nurses, for example social support. While the advice for the hospital is to reduce the activities that make-female nurses so tired, and provide time off when it is Necessary to reduce conflicts that occur.
\end{abstract}

\section{INTRODUCTION}

Organizational effectiveness concept is a more crucial concept in understanding organizational sciences (Yuniawan et al., 2017). Quality human resources is indispensable as a supporter of the organization's progress. Ranihusna, (2010) said that human resources is a challenge for management, because management and other success depends on the quality of human resources. Human resources have an important role both individually and groups and human resources are one of the main drivers of fluency the course of business activities, even the back and forth of the company is determined by existence its human resources (Ghoniyah \& Masurip, 2011).

Qualified human resources are not only determined by how high their intellectual intelligence is but also by the emotional intelligence and spiritual intelligence they have (Masitoh \& Sudarma, 2019). Human Resources (HR) is the most important asset in an organization that can move other resources. Human resources too as a central factor of an organization (Irawan \& Sudarma, 2016). The last few years of economic, social, and culture has an impact on the working lives of individuals and on companies. To achieve organizational performance good, it needs employees with good performance also (Murniasih \& Sudarma, 2016).

The success of a company in achieving its goals does not only depend to the existing facilities and infrastructure, however also depends on the performance of its employees (Susanti \& (C) 2020 Universitas Negeri Semarang

\footnotetext{
Correspondence Address:

L2 Building, 1st Floor, Faculty of Economics, Universitas Negeri Semarang

Jalan Taman Siswa, Sekaran, Gunungpati, Semarang, 50229

E-mail: lailatulmaghfiroh113@gmail.com
}

ISSN 2252-6552 
Palupiningdyah, 2016). One effect is very rapid economic growth characterized by the growth of new industries that created opportunities for the labor force both men and women (Ashar \& Harsanti, 2016). The increasing number of women working associated with higher levels of education were owned by women, which is usually women who have high levels of education are likely to pursue a business career and also his professional (Crawford \& Popp, 2000).

As for some reason despite being married working women including the following: according to Handini et al. (2014) women are motivated to work for three reasons: the need for the economy, there are certain aspects of the role in the family that motivates women to seek alternative activities outside the home, such as boredom, to meet the psychological needs, such as social status and social contacts, realization of potential, as well as desire to be useful to society (Septyaningsih \& Palupiningdyah, 2017). In the workplace women contribute not only at the level of technique but also had reached the level of strategic policy (Ranihusna \& Wulansari, 2015).

Gundelach and Kreiner (2004). Life satisfaction is the degree to which the individual assessments of the quality of life they are fun and this can be equated with happiness. Work family conflict can lead to strees work because of workfamily conflict is forcing someone to portray behavior that is contrary to a different authority (Nurmayanti et al., 2018). Family activities play a role in determining life satisfaction, then when the work greatly affects the result is a low family activity. Women life satisfaction career was his job to interfere in family life to report lower life satisfaction (Kadir, 2001).

Life satisfaction becomes important to considered. Modern organizational life, life satisfaction of employees used as a measure of maturity level of the organization, and a sign that the organization is well managed (Sulimah \& Wulansari, 2018). Job satisfaction is a pleasant emotional state of individual related to his/her job. Job satisfaction reflects the individual feeling towards his/her job (Martono \& Wulansari, 2018). Usually someone is difficult to balance their time between work and family so that the level of a person's life satisfaction decreases. Dual role conflict can be interpreted as a condition in which an individual is has 2 roles namely as employees in organization and as part of the family, and has limitations in fulfilling responsibility of one of the roles because of the role the other (Septyaningsih \& Palupiningdyah, 2017).
This is in line with previous research which states that work family conflict and family work-related conflict negative and significant one's work and life satisfaction (Kossek \& Ozeki, 1998; Mesmermagnus \& Viswesvaran, 2005). So that individuals who are more interested in the job rather than work-family conflict and stress levels psychology keluaga higher and lower life satisfaction (Greenhaus et al., 2003).

In addition to the work-family conflict can lower life satisfaction a person, work-family conflict can also affect the work life balance (Karckay \& Bakalım, 2017). On the other hand, high work targets and demands on employees also trigger stress on employees (Sanjaya, 2012).

This research supported by research Adams et al., (1996) which shows that both kind of conflict that work-family conflict and family-work conflict have a negative effect on work and family life, and can affect physical health and psychological well-being. Work life balance is something that a person's creating a balance between work and life, or can be referred to by providing a degree of interest or the same value on work and their lives (Aggarwal, 2015). Some studies involving work life balance to reduce conflict within the work (Balunos, 2015). Thing is in line with Kim (2014) who found work life balance occurs when there are no conflicts.

In addition to work life balance is a factor of life satisfaction, attachment work can increase a person's life satisfaction (Hakanen \& Schaufeli, 2012). According to Fay and Luhrman in (Lin, 2010) found that the high level of work engagement closely on customer satisfaction and employee commitment. The higher the working attachment the satisfaction and commitment of employees is also higher.In addition to testing the direct effect, this study will also examine the role mediating variables in the relationship work life balance work family conflict and work engagement against life satisfaction. Balancing the demands of jobs and family is a major challenge for the employees and the organization (Valcour, 2007).

This study was conducted in one hospital in Kendal, namely Home Muhammadiyah Islamic Hospital Kendal. Hospitals have been selected the results of observations on unstructured interviews indicated that most Kendal RSI experienced nurses work famlily conflict. Based on interviews at several nurses can be seen thatmost of them are already married and have children. Interviews showed that nurses experienced RSI Kendal demands of the role as a wife and mother 
of their children who have to perform tasks and responsibilities in the family. These results make nurses feel overburdened and can lower morale can have an impact on their life satisfaction. In addition to pressure from the family, the nurses also felt pressure at work from patients or relatives of patients who make loads and nurses increased responsibility. The increasing number of inpatients make nurses feel fatigue in the workplace and can not do things at home like cleaning the house, cooking, and taking care of her husband and children. so that Kendal RSI indicated nurses experienced low life satisfaction because too much of the load at work, and little time to enjoy daily life. Thus, it can be interpreted that the life satisfaction of female nurses RSI Kendal is still not optimal. based on phenomenon and the research gap.

\section{Hypothesis Development \\ Effect of Work Family Conflict on Life Satisfaction}

Work family conflict is a form of inter-role conflict in which the claim, time, and the tension that comes from jobs that interfere with a person to carry out its responsibilities in the family (Netemeyer et al., 1996). A person who is experiencing family conflict work will feel the pressure on his work and feel that the work he did spend a lot of time thus reducing the time to spend with his family (Van Steenbergen et al., 2014). The high level of work family conflict will have an impact on the level of satisfaction individual. Family activities play a role in determining life satisfaction, then when work greatly affect family activity then the result is satisfaction a low life. Therefore, work family conflict affects life satisfaction directly. This is in line with research Seng et al. (2009) found that work-family conflict affect job satisfaction and life satisfaction at women in Malaysia. Based on the description of the development of the above hypothesis then compiled the following hypotheses:

H1: Work family conflict can decrease life satisfaction nurse married woman at RSI Muhammadiyah Kendal.

\section{Effect of Work Engagement on Life Satisfaction}

Work engagement interpreted as engagement, satisfaction and enthusiasm in conducting individual work (Harter, Schmidt, L., \& Keyes, 2002). When employees are bound, they help in generating a balance between work and life of their own through the inherent properties of the characterize the workplace attachment $(\mathrm{Mu}-$ jiasih, 2015). The inherent nature owned also can result in greater satisfaction on health, life and work. Research has revealed that the engagement work and life satisfactionhave a positive relationship when an individual works (Körner et al., 2012). This line of research Hakanen and Schaufeli (2012) employees bound have a positive influence in the various domains of life outside the home (work) and improve the well-being and life satisfaction Based on the description of the development of the above hypothesis then compiled the following hypotheses:

$\mathrm{H} 2$ : Work engagement can increase life satisfaction nurse married woman at RSI Muhammadiyah Kendal.

\section{Effect of Work Family Conflict at Work Life Balance}

The relationship between work and family life is a two-way different. Work family conflict can have negative impacts for himselfself, family, and the organization in terms of balancing the time and role (Karckay \& Bakalım, 2017). When women work experience work-family conflict they had difficulty in establishing balance in the lives of the two domains. So the higher the workfamily conflict is felt, the lower the perceived work life balance working mothers. This is in line with research Frone (2000) states that the work family conflict and family conflict negatively and significantly related to phsycological well being. Based on the description of the development of the above hypothesis then compiled the following hypotheses:

H3: Work family conflict can reduce the work life balance nurse married woman at RSI Muhammadiyah Kendal.

\section{Effect of Work Engagement on Work Life Balance}

Work engagementis basically a condition of positive thinking regarding employment, characterized by the presence of the full condition spirit, full involvement, and high concentration during work (Schaufeli, 2002). Research shows that when employees are bound, they help in generating a balance between work and life of their own through the in here not properties of the characterize the workplace attachment (Rothbard, 2011). This study is in line with Hakanen and Schaufeli (2012) shows the results. Similar that there is a positive influence on the work of attachment domains of life outside the home and improve the well-being and life satisfaction. Based on the description of the development of the above hypothesis then compiled the following hypotheses:

H4: Work engagement can improve the work life 
balance nurse married woman at RSI Muhammadiyah Kendal

\section{Effect of Work Life Balance in Life Satisfaction}

Life satisfaction is based on the individual person's satisfaction withhas an important role of life and work life balance whether there is life (Pavot \& Diener, 2008). Work life balance effect various outcomes including job satisfaction, life satisfaction houses and overall life satisfaction (Greenhaus \& Powell, 2006). The researchers argue that a person who reached the work life balance in participation in work activities and the role and meaningful life in life will experience less stress (Marks \& MacDermid, 1996).

Similarly, married women employees in the event of an increase inbalance between work life and personal life, it will increase their life satisfaction. This research is in line with research Greenhaus and Powell (2006) found that the work life balance affect a variety of results including job satisfaction, life satisfaction and overall satisfaction at home. so that the higher the work life balance that one feels it will increase life satisfaction anyway. Based on the description of the development of the above hypothesis then compiled the following hypotheses:

H5: Work life balance can increase life satisfaction nurse married woman at RSI Muhammadiyah Kendal.

\section{Effect of Work Family Conflict on Life Satisfaction through Work Life Balance}

Work family conflict occurs because of the pressure of the role of work contrary to stress the role of the family (Nature, 2017). When women work experience role conflict in his life would have a bad impact in his life, one of which is life satisfaction. Life satisfaction is on an overall assessment of feelings and attitude towards life (Diener, 1985). Life satisfaction include an functions are interrelated with other functions such as work, family, and others.

When someone is having a conflict perandimana working women faced with two different roles that will certainly work and family effect on their life satisfaction. Therefore, women working play two roles simultaneously will decline in satisfaction life because they are not able to determine the role of family or work which must take precedence. Work life balance is something that a person's creating a balance between work and life.the balance between work and personal lives of employees can help employees faces two or more employees demand to be met.
This matter in line with research Haar (2014) who found that the work life. Balance has an indirect impact or able to mediate the relationship between enrichment work conflict and work towards the satisfaction of life of older people working and non-working parent. Based on the description of the development of the above hypothesis then compiled the following hypotheses:

H6: Work life balance mediates the relationship at work conflict pada family life satisfaction nurse married woman at RSI Muhammadiyah Kendal.

\section{Influence Work Engagement on Life Satisfac- tion Through Work Life Balance}

Entanglement of employees have a positive influence on profession. Employees who are engaged will work with passion and feel a deep connection to the company or organization they work. The high level of attachment work is closely related to one's commitment and satisfaction (Lin, 2010)

When employees are involved, can help in generating balance between work and life of their own through the inherent properties such vigor that characterize the working attachment (Rothbard, 2011). So will result in greater satisfaction on health, employment, and their lives (Wrzesniewski, 2012). This is in line with research Cain (2018) which shows that there is an indirect influence on the work life balance attachment relationship of work and life satisfaction. Based on the description of the development of the above hypothesis then compiled the following hypotheses:

H7: Work engagementcan improve life satisfaction through the work life balance of female nurses at RSI Muhammadiyah Kendal.

Based on the description of the development of the above hypothesis then compiled research model that can be seen in Figure 1 below:

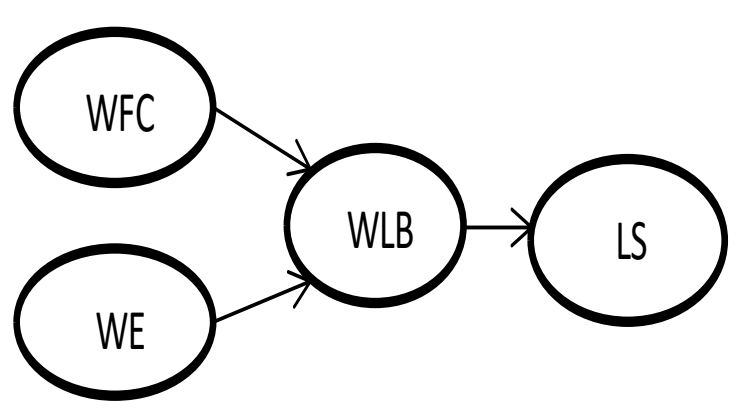

Figure 1. Research Model 


\section{METHOD}

Type of research is descriptive, The design of this research using quantitative methods. The population of the study This is the entire inpatient nurse executive women working in the Hospital Islam Muhammadiyah Kendal 168 married female nurses. While the sample is based on a calculation formula as much as 118 nurses slovin married woman. The sampling technique in this research isproportional random, Data collection through questionnaire using a Likert scale of 1-5, observations, and interviews with nurses and head nurses' station. Data were analyzed using descriptive analysis, hypothesis testing, path analysis, Sobel test using SPSS version 23.

Variables in this research work family conflict (X1) with a working pressure indicator, the number of the demands of the task, busy with work, lack kebersaman with family, conflict of commitment and responsibility towards the family. Variable work engagement (X2) with indicators of passion, dedication, and appreciation. Variable work life balance $(\mathrm{Z})$ with employment indicators disturb private life, personal life interfere with work, personal life improve performance, improve job personal life. Variable life satisfaction with an indicator of satisfaction with life today.

\section{RESULTS AND DISCUSSIONS}

\section{Validity test}

Validity test used to measure whether a valid or invalid questionnaires (Ghozali, 2016). A questionnaire is declared invalid if there are questions in the questionnaire were able to uncover something that can be measured by the questionnaire. A statement items considered valid if $r$ count $>r$ table $(0.361)$. The number of respondents in the test the validity of this study were 30 respondents. So the value is 28 denganperhitungan $\mathrm{df}, \mathrm{df}=30-2=28$.

Test the validity of this research diolahmenggunakan SPSS version 23. In a study This test statement item 49 , wherein the variable work family conflict consists of 20 statements, 11 statements engagement work, work life balance 10 statement, and life satisfaction 8 statement.

Validity test results on variable work family conflict showed that 19 items have the statement $r$ count $>r$ table. $R$ count value obtained from a number of samples $(\mathrm{n})=30$, with a significance level of $5 \%$ is 0.361 . Item statement on work family conflict variable of articles Nete- meyer, (1996). With examples as follows: "The demands of my work interfere with life home with my family ". Thus we can say that 19 items of work family conflict statement to be stated is valid and can be used in data collection selanjutna. While one statement item of work family conflict is declared invalid and can not be used in data collection.

The test results on the validity of work engagement variables showed that 10 items of the statement has $r$ count $>r$ table. $R$ count value obtained from a number of samples $(n)=30$, with a significance level of $5 \%$ is 0.361 . Item statement for a variable work engagement of articles Schaufeli \& Bakker, (2006). The following example"I was very excited when working "Thus it can be said that the 10 items of the statement of work engagements to be stated is valid and can be used in data collection selanjutna. While one item of work engagement statement is declared invalid and can not be used in data collection.

Validity test results on work life balance variables showed that 10 items of the statement has $r$ count $>r$ table. $R$ count value obtained from a number of samples $(\mathrm{n})=30$, with a significance level of $5 \%$ is 0.361 . Item statement for a variable work life balance of articles Fisher, Bulger, and Smith, (2009). With examples as follows: "I can still do activities that I want at home though tired after work" Thus it can be said that the 10 items of the statement of work life balance to be stated is valid and can be used on subsequent data retrieval.

Validity test results on life satisfaction show that 8 statement items have $r$ count> $r$ table. $R$ count value obtained from a number of samples $(n)=30$, with a significance level of $5 \%$ is 0.361 . Item statement for a variable life satisfaction of articles Pavot \& Diener (1993). With examples as follows: "I am happy with the life that I can at this time when it became a nurse and housewife". Thus it can be said that the statement of 10 items of life satisfaction to be stated is valid and can be used on subsequent data retrieval.

\section{Reliability Test}

A variable is said to be reliable (reliable) if it has a value Cronbach Alpha $>0.70$. Test diolahdengan reliability in this study using SPSS version 23.

Based on SPSS output results showed that the Cronbach Alpha value for the variable work family conflict amounted to $0.896>0.70$, Cronbach Alpha value for the variable work engagement of $0.892>0.70$, Cronbach Alpha value 
for the variable work life balance amounting to 0.861>0.70, and Cronbach Alpha value for the variable life satisfaction of $0.915>0.70$. It can be concluded that all of the variables in this study had a Cronbach Alpha values greater than 0.70. That is, the variable work family conflict, work engagement, work life balance and life satisfaction said to be reliable.

Respondents in this study a total of 116 nurses a married woman in Islam Muhammadiyah Hospital Kendal. Based on the results of data processing, as much as $3 \%$ of respondents aged $23-25$ years, $30 \%$ aged $26-28$ years, $21 \%$ of respondents in the age range $29-31$ years, $7 \%$ of respondents aged $32-24$ years, by $10 \%$ in age range $35-37$ years, $12 \%$ of respondents in the age of 38 40 years, $11 \%$ of respondents in the age range 41 43 years, and as much as $3 \%$ in the age range $44-$ 46 years. The tenure of the respondent 1-3 years at $16 \%, 39 \%$ of respondents with 4-6 years of work a long time, $28 \%$ of respondents with work $7-10$ years old, and $14 \%$ for respondents with working time $>10$ years. Respondent marriage age $<5$ years of $57 \%, 18 \%$ of respondents in the age of marriage $>5$-year and $23 \%$ for responden ts with marriage $>10$ years.

\section{Descriptive analysis}

This analysis was conducted to determine the general perception of respondents regarding the variables studied. The analysis was done using analysis techniques index numbers to describe the perception of respondents on the items to questions (Ferdinand, 2014). Based on research that has been done, the result of analysis descriptions in Table 1.

Based on the deskriptive analysis, all variables in this study included in the medium category. It shows that the respondents in this study still need to pay attention to the psychological well-being of nurses, to perform resource management in the form of demands of the role, bondage nurse, life balance and satisfaction derived.

Table 1. Descriptive Analysis

\begin{tabular}{lrl}
\hline \multicolumn{1}{c}{ Variables } & Index & Category \\
\hline Work family conflict & 31.49 & Low \\
\hline Work engagement & 40.89 & Low \\
\hline Work life balance & 43.28 & Low \\
\hline Life satisfaction & 55.08 & Medium \\
\hline
\end{tabular}

\section{Hypothesis testing \\ Statistic Test}

Ghozali (2016) revealed $t$ test statistic used to show how much influence one variable bebasdalam describes a single variable regression analysis of this study terikat.Dalam digunakanuntuk determine the correlation of variables independenyaitu work family conflict, work engagement and work life balance against the dependent variable life satisfaction. Testing is done by using a significance level of 0:05 ( $\alpha=$ $5 \%$ ). Determination reception mediation effect seen by comparing the value of $t$ and $t$ table which is known through the test path analysis (path analysis).The decision to test the indirect relationship between variables, namely performed by comparing the coefficient of direct influence to coefficient indirect effect. If the number of indirect influence coefficient $>$ directly influence the mediation hypothesis is accepted. Based on research data obtained from the questionnaire, the results of hypothesis testing can be seen in Table 2 and 3.

Table 2. Results of Hypothesis Test

\begin{tabular}{|c|c|c|c|}
\hline & Coefficients $^{\mathrm{a}}$ & & \\
\hline \multirow{2}{*}{ Model } & $\begin{array}{l}\text { standardized } \\
\text { Coefficients }\end{array}$ & \multirow[t]{2}{*}{$\mathbf{T}$} & \multirow{2}{*}{ Sig. } \\
\hline & Beta & & \\
\hline (Constant) & & 2.796 & 0.006 \\
\hline WFC & -0.011 & -0.108 & 0.914 \\
\hline WE & 0.251 & 2.537 & 0.013 \\
\hline WLB & 0.355 & 3.646 & 0.000 \\
\hline
\end{tabular}

Table 3. Results of Hypothesis Test

\begin{tabular}{|c|c|c|c|}
\hline \multicolumn{4}{|c|}{ Coefficients $^{\mathrm{a}}$} \\
\hline \multirow[t]{2}{*}{ Model } & $\begin{array}{l}\text { standardized } \\
\text { Coefficients }\end{array}$ & $\mathbf{T}$ & Sig. \\
\hline & Beta & & \\
\hline (Constant) & & 7.157 & 0.000 \\
\hline WFC & -0.319 & -3580 & 0.001 \\
\hline WE & 0.339 & 3796 & 0.000 \\
\hline
\end{tabular}

Partial statistics test the influence of work family conflict on life satisfaction can be seen in Table 3, where the value of the $t$ test for variable work family conflict of -0.108 with a significance level of $0.914>0.05$. So we can conclude that $\mathrm{H} 1$ which states that the work family conflict negative 
effect on life satisfaction is rejected. The results showed that although the significance of female nurses experience work family conflict it has absolutely no effect on life satisfaction nurse or work done indicates that nurses do not interfere with family life and in the workplace The results are consistent with research Sulistiawan and Armuninggar (2017) which found that the work family conflict experienced by physicians having influence on life satisfaction physician at Hospital Dr. Soetomo. These results are shown in Table 3.

The study also approve thr statistical test work pengruh partial engagement in life satisfaction can be seen Table 3, where the value of the $t$ test for variable work engagement of 2.537 with 0.013 significance level of $<0.05$. So we can conclude that the results of these studies indicate that $\mathrm{H} 2$ engagment stated that work has a positive effect on life satisfaction nurse married woman received. The results showed that the significant value of work engagement have an influence on the level of life satisfaction of female nurses. While directions positive relationship indicates that if work engagement owned by high nurse would increase life satisfaction nurses, and otherwise if work engagemnt held low, the nurse satisfaction nurse living will decline. The results are consistent with research Korner (2012) revealed that work engagement and life satisfaction have positive relationship when an individual working spirit.

Statistical test work family conflict partial influence on work life balance can be seen in Table 2 , where the value of the $t$ test for variable work family conflict by -3.580 * with a significance level of $0.001<0.05$. It shows that $\mathrm{H} 3$ which states that work family conflict negative effect on work life balance is accepted. direction reveals that a negative relationship when the work family conflict perceived by high female nurses will decrease the work life balance nurses, and vice versa when the work family conflict perceived female nurses low, the work life balance of perceived nurses assessed will increase. The results are consistent with previous research conducted by Frone (2000) who found that the work family conflict and family conflictand significant negative relation phsycological well being.

Statistical test partial engagement work on work life balance can be seen in Table 2, where the value of the $t$ test for variable work engagement of 3.796 with 0.000 significance level of $<0.05$. The results showed that $\mathrm{H} 4$ which states that the work engagment have a positive effect on work life balance female nurses received. The results showed that the significant value of work en- gagement have an influence on the level of work life balance of female nurses. While the direction of a positive relationship indicates that if work engagement owned by high nurse will increase the work life balance of nurses it, and vice versa when the work engagemnt owned low nurse then work life balancenurse will decline. The results are consistent with research. Hakanen and Schaufelli (2012) which states that employees have the attachment (engaged worker) have a positive influence in the various domains of life outside the home (work) and improve a person's psychological wellbeing and life satisfaction.

Statistical test work life balance partial influence on life satisfaction nurse married woman can be seen in Table 2, where the value of the variable $t$ test unruk work life balance amounted to 3.646 with a significance level of $0.000<0.05$. So it can be concluded that the H5 stated that the work life balance has a positive effect on life satisfaction female nurses received. The results showed that the significant value of work life balance have an influence on the level of life satisfaction of female nurses. While the direction of a positive relationship indicates that if work life balance owned by high nurse will increase the life satisfactionperawat it, and vice versa when the work life of nurses owned balanceyang lower then life satisfaction nurse will decline. The results are consistent with research Brough et al. (2014) which stated that the work life balance has a positive influence on satisfaction life.

\section{Path Analysis Test}

Path analysis is the use of regression analysis to estimate the causal relationships between variables are predetermined based on the theory (Ghozali, 2011).

In this study will examine the effect of work family conflict and work engagement through work life balance. For measure the presence or absence of the effect of mediation,

Following are the results of direct relationship calculation, indirect relationship, and total relationship Indirectly between work family conflict variables, work engagement work life balance on life satisfaction is first performed a path coefficient comparison. The path coefficient is calculated by making two regression model equations. The regression equation in this study is as follows:

\section{Regression I}

$$
\begin{aligned}
& \mathrm{WLB}=\mathrm{b} 1 \mathrm{WFC}+\mathrm{b} 2 \mathrm{WE}+\mathrm{e} 1 \\
& \mathrm{WLB}=(-0.319)+0,339 \mathrm{WE} \mathrm{WFC}+0.81
\end{aligned}
$$


Regression II

$\mathrm{LS}=\mathrm{b} 1 \mathrm{WFC}+\mathrm{b} 2 \mathrm{WE}+\mathrm{b} 3 \mathrm{WLB}+\mathrm{e} 2$

$\mathrm{LS}=(-0.011) \mathrm{WFC}+0,251 \mathrm{WE} \mathrm{WLB}+0.85+0.355$

The following results hubungan masing path analysis of the variables that ditampilkan melalui image below:

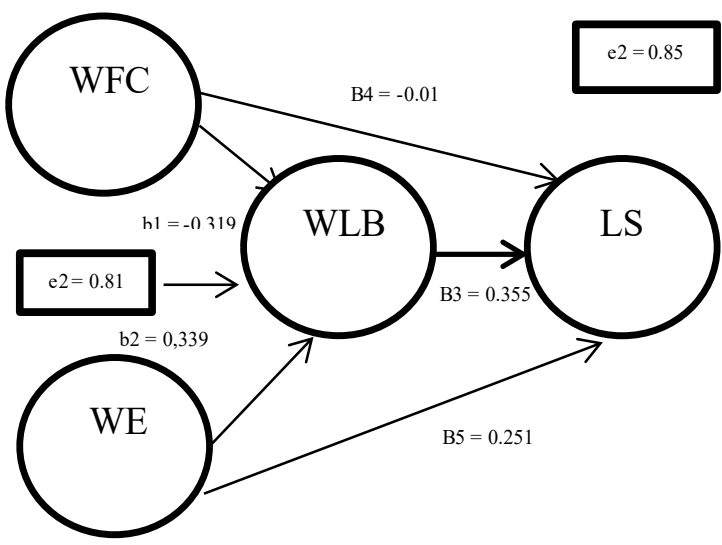

Figure 2. Path Analysis

Tabel 4. Direct and Indirect Effects of Work Family Conflict and Work Engagement on Life Satisfaction through Work Life Balance

\begin{tabular}{ccccr}
\hline Var. & Effect & WLB & LS & \multicolumn{1}{c}{ Total } \\
\hline WFC & Direct & - & -0.011 & -0.011 \\
\hline & Indirect & -0.319 & 0.355 & $\begin{array}{r}-0.319 \times 0.355 \\
=-0.113\end{array}$ \\
& & & & $\begin{array}{r}-0.011+ \\
-0.113)= \\
-0.124\end{array}$ \\
Total & & & & 0.251 \\
& & & & $0.339 \times 0.355$ \\
WE & Direct & & 0.251 & $=0.120$ \\
\hline & \multirow{2}{*}{ Indirect } & 0.339 & 0.355 & $\begin{array}{r}0.351+0.120 \\
\end{array}$ \\
& & & & 0.371 \\
\hline & Total & & & 0.251
\end{tabular}

Based on table 4 direct and indirect effects of work family conflict on life satisfaction through work life balance shows that the direct effect of -0.011 while the total effect of -0.124 . So that it can be concluded that the total influence of $-0.124<-0.011$ (direct effect), it can be concluded that the work life balance is not able to be mediated in this study. That is, H6 which states that work life balance mediates the relationship between work family conflict and life satisfaction is rejected. While the direct and indirect influence of work engagement on life satisfaction through work life balance shows that the direct effect is 0.251 while the total effect is 0.371 . It can be concluded the magnitude of the total effect of $0.371>$ 0.251 (direct effect), it can be concluded that the work life balance in this study is able to mediate the relationship of work engagement and life satisfaction. That is, $\mathrm{H} 7$ which states that work engagement can increase life satisfaction through work life balance is accepted.

\section{CONCLUTION AND RECOMMENDATION}

The conclusion of this study is Work family conflict has a negative but not significant effect on the life satisfaction of female nurses at RSI Kendal. Work engagement has a positive and significant effect on the life satisfaction of female nurses at RSI Kendal. Work family conflict has a negative and significant effect on the work life balance of women nurses at RSI Kendal. Work engagement has a positive and significant effect on the work life balance of RSI Kendal female nurses. Work life balance has a positive and significant effect on the life satisfaction of RSI Kendal female nurses. Work life balance cannot mediate the relationship of work family conflict in the life satisfaction of RSI Kendal female nurses. Work life balance can mediate the relationship of work family conflict in the life satisfaction of RSI Kendal female nurses.

In conducting this research, of course the author is not spared limitations. In this study, the sample used was only 118 samples so the results could not be generalized. The recommendation for further research is to conduct research on objects other than hospitals by increasing the number of samples used. Future studies can also examine other variables such as social support to increase the life satisfaction of women who experience multiple roles.

\section{REFERENCES}

Adams, G. A., King, L. A., \& King, D. W. (1996). Relationships of Job and Family Involvement , Family Social Support, and Work-Family Conflict With Job and Life Satisfaction. Journal of Applied Psychology, 81(4).

Anwar, H. (2014). Hubungan Antara Otonomi Kerja, Orientasi Peran Gender Keluarga, Keseimbangan Keja-Keluarga Dengan Kepuasan Kerja dan Kepuasan Keluarga Pada Perempuan Yang Berperan Ganda. Instuisi Jurnal Ilmiah Psikologi, 6(2), 61-67.

Ashar, A., \& Harsanti, I. (2016). Hubungan Work Family Conflict dengan Quality Of Work Life Pada Karyawan Wanita Perushaan Swasta. Ju- 
rnal Ilmiah Psikologi, 9(2).

Brough, P., Timms, C., Driscoll, M. P. O., Siu, O., Sit, C., \& Lo, D. (2014). The International Journal of Human Work - life balance : a longitudinal evaluation of a new measure across Australia and New Zealand workers. The International Journal of Human Resources Management, 25(19)

Cain, L., Busser, J., \& Kang, H. J. (2018). Executive chefs' calling : effect on engagement, work-life balance and life satisfaction, 30(5).

Crawford, M., \& Popp, D. (2000). Sexual double standards: A review and methodological critique of two decades of research Sexual Double Standards : A Review and Methodological Critique of Two Decades of Research. The Journal of Sex Research, 40(1).

Ferdinand, A. (2014). Metode Penelitian Manajemen Pedoman Penelitain untuk Penulisan SKripsi Tesis dan Disertasi Ilmu Manajemen (5th ed.). Semarang: Badan Penerbit Universitas Diponegoro.

Fisher, G. G., Bulger, C. A., \& Smith, C. S. (2009). Beyond Work and Family : A Measure of Work / Nonwork Interference and Enhancement. Journal of Occupational Health Psychology, 14(4).

Ghoniyah, N., \& Masurip. (2011). Peningkatan Kinerja Karyawan Melalui Kepemimpinan, Lingkungan Kerja dan Komitmen, 2(2).

Ghozali, I. (2011). Ghozalli, I Aplikasi Analisis Multivariate dengan Program IBM SPSS 19 (4th ed.). Semarang: Universitas Diponegoro.

Gundelach, P., \& Kreiner, S. (2004). Happiness and Life Satisfaction in Advanced Peter Gundelach. Cross Cultural Research, 38(4).

Handini, R. E., Haryoko, S. F., \& Yulianto, A. (2014). Hubungan antara work-family conflict dan keterikatan kerja pada ibu bekerja. Jurnal NOETIC Psychology, 4(2).

Irawan, L., Sudarma, K., Manajemen, J., Ekonomi, F., Semarang, U. N., \& Artikel, I. (2016). Pengaruh keadilan distributif dan keadilan prosedural pada komitmen afektif melalui kepuasan kerja, 5(2).

Kadir, R. A. (2001). Pengaruh Karier, Konflik Pekerjaan-Keluarga Terhadap Kepuaan Hidup Wanita Karier Di Jateng dan Yogyakarta.

Martono, S., \& Wulansari, N. A. (2018). Remuneration Rewards Management System As A Driven Factor Of Employee Perfomance, 19.
Masitoh, S., \& Sudarma, K. (2019). The Effect Of Emotional Intelligence And Spiritual Intelligence On Work Satisfaction With Employee Perfomance As Intervening Variable. Management Analysis Journal, 8(1).

Murniasih, E., \& Sudarma, K. (2016). Pengaruh Persepsi Dukungan Organisasi Dan Kompetensi Pada Kinerja Karyawan Komitmen Afektif. Management Analysis Journal, 5(1).

Nurmayanti, S., Sakti, D. P. B., Putra, I. N. N. A., \& Wardani, L. (2018). Pengaruh Konflik Pekerjan-Keluarga Terhadap Kepuasan Kerja dan Kepuasan Hidup (Studi Pada Perempuan Etnis Bali Yang Bekerja di Kota Mataram). Jurnal Ilmu Manajemen Dan Bisnis, 6(2).

Ranihusna, D. (2010). Efek Rantai Motivasi Pada Kinerja Karyawan. Jurnal Dinamika Manajemen, $1(2)$.

Ranihusna, D., \& Wulansari, N. A. (2015). Reducing The Role Conflict Of Working Woman : Between Work And Family Centrality. Jurnal Dinamika Manajemen, 6(2).

Sanjaya, F. (2012). Peran Moderasi Kecerdasan Emosi Pada Stress Kerja. Jurnal Dinamika Manajemen, 3(2).

Septyaningsih, R., \& Palupiningdyah. (2017). Pengaruh Beban Kerja Berlebih Dan Konflik Pekerjaan Keluarga Terhadap Kinerja Melalui Kelelahan Emosional. Management Analysis Journal, 6(4).

Sulimah, \& Wulansari, N. A. (2018). When Conflict be a Trigger of Depression : between Job and Life Satisfaction Ketika Konflik Menjadi Pemicu Depresi : antara Kepuasan Kerja dan Kepuasan Hidup. Jurnal Dinamika Manajemen, 9(36).

Susanti, \& Palupiningdyah. (2016). Pengaruh Kepuasan Kerja dan Komitmen Organisasi Terhadap Kinerja Karyawan Dengan Turnover Intention Sebagai Variabel Intervening. Management Analysis Journal, 5(1)

Yuniawan, A., Putri, V. W., \& Udin. (2017). Developing An Alternative Model For The Relationship Among Social Capital, Adaptive-Integrative Leadership, Competitive Advantage, And Organizational Effectiveness. International Journal of Civil Engineering and Technology, 8(11). 